УдК 343.98:331.4

DOI https://doi.org/10.32837/pyuv.v0i4(39).918

\author{
К. О. Спасенко \\ orcid.org/0000-0002-7481-7318 \\ кандидат юридичних наук, \\ асистент кафедри криміналістики \\ Національного юридичного університету імені Ярослава Мудрого
}

\title{
ОСОБЛИВОСТІ ПРИЗНАЧЕННЯ ТА ПРОВЕДЕННЯ СУДОВИХ ЕКСПЕРТИЗ ПРИ РОЗСЛІДУВАННІ ЗЛОЧИННИХ ПОРУШЕНЬ ПРАВИЛ БЕЗПЕКИ ПІД ЧАС ВИКОНАННЯ РОБІТ ІЗ ПІДВИЩЕНОЮ НЕБЕЗПЕКОЮ
}

Постановка проблеми. Розслідування злочинних порушень правил безпеки під час проведення робіт із підвищеною небезпекою з метою встановлення всіх обставин кримінального правопорушення вимагає застосування спеціальних знань. Актуальним видається дослідження застосування спеціальних знань під час розслідування порушень правил безпеки, передбачених ст. 272 Кримінального кодексу України ( ППорушення правил безпеки під час виконання робіт із підвищеною небезпекою»).

Аналіз останніх досліджень i публікацій. Науково-теоретичне підгрунтя статті становлять праці багатьох учених, серед яких: Т.В. Авер'янова, Р.С. Бєлкін, А.І. Вінберг, Н.І. Клименко, М.Я. Сегай, І.Я. Фрідман, В.О. Коновалова, В.Ю. Шепітько, О.Р. Шляхов та інші.

Метою статті є дослідження особливостей призначення та проведення судових експертиз при розслідуванні порушень правил безпеки під час проведення робіт із підвищеною небезпекою.

Виклад основного матеріалу. Особливість застосування спеціальних знань під час розслідування зазначеної категорії злочинів полягає у специфіці порушень правил безпеки у процесі проведення робіт із підвищеною небезпекою, а отже, й у переліку необхідних для проведення експертиз питань, що потребують вирішення, а також у варіативності такого переліку, залежно від виконуваних робіт, виду негативних наслідків та інших елементів криміналістичної характеристики. Наприклад, під час розслідування порушень правил безпеки у процесі виконання робіт на висоті з негативними наслідками у вигляді тілесних ушкоджень постає необхідність у проведенні інженерно-технічної експертизи з охорони праці, судово-технічної будівельної експертизи, судово-медичної експертизи. Наголосимо, що важливе значення мають техніко-криміналістичні засоби, які застосовуються в експертних дослідженнях. Завдяки ним експерти-криміналісти вирішують питання, які відіграють вагому роль у розслідуванні зазначеної категорії злочинів [1, с. 156].

Методика експертних досліджень у провадженнях, пов'язаних із порушенням правил безпеки під час проведення робіт із підвищеною небезпекою, грунтується на загальній методології судової експертизи та складається $з$ таких стадій: 1) підготовчої (попереднє дослідження); 2) основного дослідження (аналітична, порівняльна, синтезувальна стадії); 3) заключної (постановка висновку) [2, с. 44-98].

Відповідно до чинного законодавства судова експертиза - це дослідження експертом на підставі спеціальних знань матеріальних об'єктів, явищ і процесів, що містять інформацію про обставини справи, яка перебуває у провадженні органів досудового розслідування чи суду [3].

Аналіз практики застосування спеціальних знань під час розслідування злочинів, передбачених ст. 272 Кримінального кодексу України, дає змогу дійти висновку про те, що у кримінальних провадженнях найбільш затребуваними $€$ допомога спеціалістів у галузі охорони праці та проведення інженерно-технічних експертиз із застосуванням спеціальних технічних знань 3 електробезпеки, пожежної безпеки, будівництва, гірничої справи тощо. Зупинимося на детальному дослідженні деяких експертиз.

Судова інженерно-технічна експертиза з охорони праці призначається з метою виявлення причинних залежностей і фактів щодо діяльності або бездіяльності робітників та посадових осіб у процесі нормального функціонування підприємства і в разі виникнення на ньому надзвичайної ситуації, недотримання трудової та виробничої дисциплін, невиконання вимог нормативно-правових актів із охорони праці та експлуатаційної документації, порушення технологічних процесів, технічного стану будинків, споруд, комунікацій, транспорту, приладів контролю, машин, механізмів, устаткування, інструментів й інших знарядь праці, а також засобів протиаварійного колективного та індивідуального захисту. Об'єктом цієї експертизи є сліди відображення у вигляді матеріальних і матеріалізованих джерел інформації, що містяться в матеріалах кримінального провадження щодо надзвичайної ситуації та досліджуються експертами (речові докази, фрагменти місця події, зразки, будинки, споруди, майдан- 
чики, комунікації, способи й засоби виробництва, системи керування, контролю та захисту, документи тощо) [4, с. 334].

Спираючись на напрацювання вчених із судової інженерно-технічної експертизи в галузі охорони праці й безпеки життєдіяльності [4, с. 336-337], можемо окреслити низку питань, що підлягають 3'ясуванню під час проведення цієї експертизи: 1) встановлення причин та обставин, ступеня тяжкості матеріально-технічних наслідків порушень правил безпеки; 2) виявлення причин порушення технологічного процесу; 3) визначення відповідності фактичних умов експлуатації машин, механізмів та обладнання вимогам нормативно-технічної документації, визначення їх технічного стану і придатності для виконання конкретних технологічних і технічних операцій; 4) з'ясування відповідності кваліфікації суб’єкта характеру виконуваних робіт; 5) з'ясування недоліків організаційного та технічного характеру у виробничому процесі; 6) визначення відповідності умов праці правилам техніки безпеки; 7) виявлення обставин, що сприяли виробничому травмуванню; 8) встановлення природних або інших явищ, які могли зумовити виникнення події (зокрема, людський фактор); 9) з'ясування відповідності поведінки осіб, причетних до події, вимогам законодавчих актів з охорони праці.

При цьому слід наголосити, що запропонований перелік питань, які підлягають з'ясуванню, є досить умовним і в конкретній ситуації може бути розширений та включати ті питання, котрі мають значення для здійснення провадження.

Правильність постановки питань, а також їх перелік має вирішувати максимальну кількість завдань, що потребують застосування спеціальних знань. Однак специфіка проведення робіт із підвищеною небезпекою та складність їх нормативного регулювання є одними з причин нехтування слідчим формуванням необхідної кількості питань експертові.

Сутність гірничо-технічної експертизи як процесуальної дії полягає в дослідженні для кримінального провадження обставин події на підприємстві гірничої промисловості, що призвела до загибелі людей або до заподіяння шкоди їхньому здоров'ю, або до інших наслідків, проведеному в передбаченому законом порядку обізнаними у гірничій справі особами. Потреба у запровадженні цієї експертизи зумовлена значною кількістю надзвичайних ситуацій (технічних аварій, нещасних випадків) на вугільних шахтах, які зазвичай спричинені людським фактором, часто мають складний та тривалий характер і в багатьох випадках супроводжуються людськими жертвами на фоні величезних економічних та екологічних збитків. Така експертиза грунтується на декількох базових науках й адаптує до потреб судової експертизи низку положень теорії гірничої справи, механіки, інженерної психології, теорії систем та управління, електротехніки [5, с. 302-303].

Предметом гірничо-технічної експертизи $€$ фактичні дані (обставини провадження), що встановлюються в процесі вивчення матеріалів кримінального провадження на підставі спеціальних пізнань у гірничій справі і включають сукупність відомостей про технічний стан устаткування, інструментів, комунікацій, гірничих виробок, провітрювання, пилогазового режиму, протиаварійного захисту, інших знарядь праці та засобів виробництва, які забезпечують функціонування гірничого підприємства [6, с. 151].

Завдання зазначеної експертизи можна об'єднати в такі групи:

- з'ясування причин та обставин техногенних аварій, що трапилися на гірничому підприємстві, й визначення ступеня тяжкості матеріально-технічних наслідків;

- з'ясування технічних причин порушень технологічного гірничого процесу;

- визначення стану гірничих механізмів і придатності їх для виконання конкретних технічних операцій;

- виявлення дефектів гірничих механізмів, технічних причин і часу їх виникнення;

- з' ясування відповідності кваліфікації суб'єкта технологічного процесу характеру роботи, що ним виконувалися;

- визначення об’єктивної можливості виконання певних дій у заданих технічних умовах;

- з'ясування недоліків організаційно-технічного характеру у виробничому процесі гірничого підприємства;

- визначення відповідності умов роботи на гірничому підприємстві вимогам техніки безпеки [7, с. 224-226].

Типовими завданнями, що можуть бути вирішені в результаті проведення гірничо-технічної експертизи, є: верифікація виду техногенної аварії на гірничому підприємстві, 3'ясування їі причин та обставин, а також ступеня тяжкості матеріально-технічних й екологічних наслідків; виявлення конкретних технічних причин порушення технологічного гірничого процесу; з'ясування відповідності фактичних умов експлуатації гірничих машин, механізмів, обладнання, інструментів вимогам нормативно-технічної документації, ïx технічному стану і придатності до виконання конкретних операцій; виявлення дефектів гірничих машин, обладнання, механізмів, а також технічних причин і часу їх виникнення; з'ясування відповідності кваліфікації суб’єкта технологічного процесу характеру робіт, що ним виконувались; з'ясування об'єктивної можливості виконання дій у заданих гірничо-геологічних та гірничотехнічних умовах; виявлення недоліків організацій- 
но-технічного характеру у виробничому процесі гірничого підприємства; з'ясування відповідності умов роботи на гірничому підприємстві і конкретному робочому місці положенням нормативів щодо охорони праці та техніки безпеки; з'ясування обставин, що сприяли виникненню професійного захворювання, виробничому травматизму або аварії на підприємстві; з' ясування послідовності явищ, що призвели до надзвичайної ситуації; 3'ясування якості застосованих матеріалів, інструментів та їх безпечності щодо проведення конкретного виду гірничих робіт; з'ясування природних або гірничо-геологічних явищ, що могли зумовити виникнення події, а також того, чи відіграв яку-небудь роль людський фактор в її виникненні; оцінка адекватності дій осіб, причетних до події, у конкретній виробничій ситуації [5, с. 305].

Судово-технічна будівельна експертиза належить до класу інженерно-технічної експертизи, за допомогою якої найбільш точно й достовірно можна встановити якість будівельних та ремонтних робіт, виконуваних на всіх етапах будівництва, ї відповідність будівельним нормам і договору, а також якість та кількість використаних будівельних матеріалів й їх відповідність вказаним у будівельно-монтажній документації.

Слід зазначити, що судово-технічна будівельна експертиза на основі спеціальних знань у галузі будівництва сприяе з' ясуванню фактичних даних щодо обставин нещасного випадку. Загальним предметом досліджень, які проводяться в межах судово-технічної будівельної експертизи, є відповідність будівельного об'єкта певній нормі, правилу, регламенту. В експертизі цього виду такі дослідження називають нормативно-технічними або нормативно-девіантними [5, с. 283-284]. До компетенції цієї експертизи входить вирішення таких питань:

- віднесення продукції до будівельного виробництва;

- технічний аналіз конструкцій, виробів і матеріалів; виконаних (виконуваних) будівельних робіт певного класу, роду, типу, виду, групи;

- визначення вартості будівельних об'єктів і виконаних робіт; ціни об'єктів нерухомості промислової, житлової та містобудівної сфери;

- з'ясування відповідності продукції будівельного виробництва, продукції виробництва будівельних конструкцій, виробів, деталей і матеріалів нормативно-технічним вимогам;

- з'ясування причин, умов, обставин і механізму аварії, нещасного випадку на будівництві;

- визначення наявності часткової або повної втрати продукцією будівельного виробництва функціональних, експлуатаційних, споживчих, естетичних властивостей і властивостей безпеки;

- з'ясування відповідності дій осіб - учасників події (аварії, нещасного випадку на будівництві), а також осіб, відповідальних за належне ведення та безпеку умов виробничого процесу, спеціальним правилам;

- можливості зміни функціонального призначення, габаритів, поверховості та інших характеристик будинків, будівель і споруд.

На вирішення судово-технічної будівельної експертизи у провадженнях про порушення правил під час проведення будівельних робіт, що не спричинили нещасних випадків із людьми, але пов'язані з настанням інших тяжких наслідків, ставляться такі запитання: 1) чи є належним чином затверджений проєкт будівельних робіт та інша необхідна проєктно-кошторисна документація; 2) чи своєчасно вона складена та затверджена; якщо ні, то чи не позначилося це на якості робіт, що спричинило тяжкі наслідки; 3) чи правильно складено проєкт будівельних робіт; якщо ні, то які допущено помилки й чим вони зумовлені; 4) чи відповідала проєкту будівельних робіт та іншим висунутим вимогам якість будівельних робіт і будівельних матеріалів; якщо не відповідала, то чи вплинули допущені відхилення на причину розслідуваної події й яким чином?

Питання, які ставляться на вирішення будівельно-технічної експертизи у провадженнях про порушення правил безпеки, що призвели до нещасних випадків із людьми, значно різноманітніші та можуть включати такий перелік:

- чи дотримані умови допуску до роботи потерпілого та інших осіб, причетних до нещасного випадку, зокрема, чи пройшли вони необхідне навчання й інструктажі;

- чи відповідали належним вимогам організація навчання працівника, рівень знань будівельних правил, правил експлуатації будівельних механізмів та інших правил, необхідних для допуску до виконуваної роботи. Зокрема, може виникнути питання, чи відповідають інструктажі, атестація, іспити вимогам якості навчання;

- чи були забезпечені потерпілі, відповідно до вимог, спеціальним одягом, взуттям, запобіжними пасками та іншими індивідуальними захисними засобами, чи правильно вони використовувалися;

- чи відповідали вимогам інші умови праці (освітлення, вентиляція, температура тощо);

- чи відповідали вимогам огородження небезпечних місць попереджувальні знаки;

- чи передбачає проєкт виконання робіт заходи, спрямовані на гарантування безпеки осіб, зайнятих на будівництві, чи відповідали ці заходи необхідним вимогам;

- чи відповідав порядок виконання робіт, за яких стався нещасний випадок, вимогам проєкту організації робіт та інструкцій [8, с. 77-78].

Висновки. Таким чином, залучення експертів і проведення судових експертиз виступають важливим засобом збирання доказів у досудовому 
розслідуванні порушень правил безпеки під час проведення робіт із підвищеною небезпекою. Водночас залучення експертів відіграє важливу роль у профілактичній роботі, тому актуальним залишається питання експертної профілактики.

\section{Jimepamypa}

1. Таран О.В. Техніко-криміналістичне забезпечення розслідування злочинів, пов'язаних із порушенням вимог законодавства про охорону праці. Криміналістика XXI столітmя : матер. наук.-практ. конф., м. Харків, 25-26 листопада 2010 р. Харків : Право, 2010. C. $153-157$.

2. Шляхов А.Р. Структура экспертного исследования и гносеологическая характеристика выводов эксперта-криминалиста. Труды ВНИИСЭ. Москва : ВНИИСЭ, 1972. Вып. 4. С. 3-112.

3. Про судову експертизу : Закон України від 25 лютого1994 р. № 4038-XII. Відомості Верховної Ради України. 1994. № 28. Ст. 232.

4. Кривченко Ю.О. Теоретичний базис судової інженерно-технічної експертизи в галузі охорони праці та безпеки життедіяльності. Теорія і практика судової експертизи і криміналістики : зб. наук. праць. 2012. Вип. 12. С. 332-339.

5. Експертизи у судочинстві України : наук.-практ. посіб. / за заг. ред. В.Г. Гончаренка, І.В. Гори. Київ : Юрінком Інтер, 2015. 504 c.

6. Судова експертиза з питань охорони праці. Гірничотехнічна експертиза. Тлумачний словник основних термінів / уклад. Ю.А. Кир'янов, Г.М. Дружинін, А.А. Крупка та ін. Донецьк : ДНДІСЕ, 2001. 196 с.

7. Бордюгов Л.Г. Зміст предмета судової гірничотехнічної експертизи. Проблеми правознавства та правоохоронної діяльності : зб. наук. праць. Донецьк : Донецький інститут внутрішніх справ, 2004. Вип. 1. С. 220-227.

8. Махов В.Н., Образцов В.А., Чернова К.Т. Расследование преступных нарушений правил при производстве строительных работ. Москва : ВНИИПП, 1979. 124 с.

\section{Анотація}

Спасенко К. О. Особливості призначення та проведення судових експертиз при розслідуванні злочинних порушень правил безпеки під час виконання робіт із підвищеною небезпекою. - Стаття.

Стаття присвячена дослідженню особливостей призначення судових експертиз при розслідуванні злочинних порушень правил безпеки під час проведення робіт із підвищеною небезпекою. З'ясовано, що методика експертних досліджень у провадженнях, пов'язаних із порушенням правил безпеки під час проведення робіт із підвищеною небезпекою, складається зі стадій: попереднього дослідження, основного дослідження (аналітична, порівняльна, синтезувальна стадії), постановки висновку. З'ясовано, що при розслідуванні злочинних порушень правил безпеки під час виконання робіт із підвищеною небезпекою найбільш затребуваним є проведення інженерно-технічних експертиз із застосуванням спеціальних технічних знань з електробезпеки, пожежної безпеки, будівництва, гірничої справи.

Наголошено, що судова інженерно-технічна експертиза з охорони праці призначається з метою виявлення причинних залежностей і фактів щодо діяльності або бездіяльності робітників та посадових осіб у процесі нормального функціонування підприємства й у разі виникнення на ньому надзвичайної ситуації, недотримання трудової та виробничої дисциплін, невиконання вимог нормативно-правових актів із охорони праці та експлуатаційної документації тощо. Сутність гірничо-технічної експертизи як процесуальної дії полягає в дослідженні для кримінального провадження обставин події на підприємстві гірничої промисловості, що призвела до загибелі людей або до заподіяння шкоди їх здоров'ю, або до інших наслідків, проведеному в передбаченому законом порядку обізнаними в гірничій справі особами. Судово-технічна експертиза допомагає найбільш точно й достовірно встановити якість будівельних і ремонтних робіт, виконуваних на всіх етапах будівництва, їх відповідність будівельним нормам і договору, а також якість і кількість використаних будівельних матеріалів та їх відповідність вказаним у будівельно-монтажній документації.

Ключові слова: розслідування злочинів, судові експертизи, проведення робіт із підвищеною небезпекою, порушення правил безпеки, порушення правил безпеки під час проведення робіт із підвищеною небезпекою.

\section{Summary}

Spasenko K.O. Features of appointment and carrying out of forensic examinations at investigation of criminal violations of safety rules during performance of works with the increased danger. - Article.

The article is devoted to the study of the peculiarities of the appointment of forensic examinations in the investigation of criminal violations of safety rules during the performance of high-risk work. It was found that the methodology of expert research in proceedings related to violations of safety rules during the performance of highrisk work consists of the following stages: preliminary research, basic research (analytical, comparative, synthesizing stages), conclusion. It is established that when investigating criminal violations of safety rules during highrisk work, the most popular are engineering and technical examinations with the use of special technical knowledge in electrical safety, fire safety, construction, mining.

It is emphasized that forensic engineering expertise on labor protection is appointed to identify causal relationships and facts about the activities or inaction of workers and officials in the normal functioning of the enterprise and in the event of an emergency, non-compliance with labor and production disciplines, non-compliance legal acts on labor protection and operational documentation, etc. The essence of mining expertise as a procedural action is to investigate for criminal proceedings the circumstances of the event at the mining industry, which led to the death of people, or to harm their health, or to other consequences, conducted in the manner prescribed by law knowledgeable in mining persons. Forensic assistance helps to most accurately and reliably establish the quality of construction and repair work performed at all stages of construction, their compliance with building codes and the contract, as well as the quality and quantity of construction materials used and their compliance with construction and installation documentation.

Key words: investigation of crimes, forensic examinations, performance of works with increased danger, violation of safety rules, violation of safety rules during performance of works with increased danger. 